\title{
HLA guided epitope discovery in Type 1 diabetes to generate novel therapeutics
}

\author{
M Peakman \\ From 5th European Workshop on Immune-Mediated Inflammatory Diseases \\ Sitges-Barcelona, Spain. 1-3 December 2010
}

Type 1 diabetes (T1D) is part of a group of disorders termed "organ-specific autoimmune diseases", involving destructive inflammation focused on the insulin-producing beta cells in the islet of Langerhans. Patients (frequently children) lose endogenous insulin production and are required to inject insulin several times per day for the remainder of their lives, and, after many years, frequently develop severe life-threatening complications affecting the kidneys, heart and eyes. Beta cell destruction is mediated by $\mathrm{T}$ lymphocytes. Our work has focused on identification of the key epitopes of beta cell autoantigens that $\mathrm{T}$ lymphocytes recognize during the development of T1D. We have characterized autoreactive $\mathrm{CD} 4 \mathrm{~T}$ cells that produce the pro-inflammatory cytokines IFN-gamma and IL-17 as well as others that make IL-10; these have potent immune regulatory properties and are present in a subset of patients who have delayed diabetes onset. More recently, we have extended our analysis of the epitope repertoire in T1D to include peptides presented by disease-associated MHC class I molecules to CD8 T cells. We have identified novel epitopes in preproinsulin that are processed by an unconventional route and are targeted by cytotoxic $\mathrm{T}$ lymphocytes (CTLs) in a high proportion of T1D patients. Finally, we have used knowledge about epitopes to explore the potential for antigen-specific immune modulation in T1D, completing a first-in-man study of proinsulin peptide immunotherapy in patients in order to generate data on safety and biomarkers, and lay the

Dept. of Immunobiology, King's College London School of Medicine, Guy's Hospital, London, UK groundwork for future intervention studies designed to examine efficacy.

Published: 25 November 2010

doi:10.1186/1479-5876-8-S1-14

Cite this article as: Peakman: HLA guided epitope discovery in Type 1 diabetes to generate novel therapeutics. Journal of Translational Medicine 2010 8(Suppl 1):14.
Submit your next manuscript to BioMed Central and take full advantage of:

- Convenient online submission

- Thorough peer review

- No space constraints or color figure charges

- Immediate publication on acceptance

- Inclusion in PubMed, CAS, Scopus and Google Scholar

- Research which is freely available for redistribution
Ciomed Central 